\title{
Analog and Digital Games as a Pedagogical Tool in the Teacher Training Context
}

\author{
Maria do Céu Ribeiro * \\ Insituto Politécnico de Bragança \\ *Corresponding Author: ceu@ipb.pt \\ Received : 04.07.2019 \\ Revision requested: 06.09.2019 \\ Accepted : $\quad$ 28.09.2019
}

How to cite this paper: Riberio, M. C. (2019). Analog and digital games as a pedagogical tool in the teacher training context. Research in Social Sciences and Technology, 4(2),163-173.

\begin{abstract}
This article focuses on analog and digital game play and the challenges it poses to future teachers in an educational context. For that, a review of the literature on the subject was made, addressing the theories of Piaget and Vygotsky. We refer to the game as a pedagogical resource, its relation to the teaching-learning process, and its role in stimulating the multiple intelligences referenced by the psychologist Howard Gardner. Structurally framed by this theoretical framework, we developed this study in an integrated internship context in a classroom of the First Cycle of Basic Education, with 20 children ages 9 and 10. In order to carry out this research, we developed teaching-learning experiences that allowed us to answer the following question: How do the different game supports (analog/digital) motivate children to the teaching-learning process? In order to answer this question, we have outlined the following objectives: i) to understand if the type of support in which children play influences learning; ii) develop activities in contexts, using games (analog and digital); (iii) understand, to what extent, playing games encourages the development of multiple skills. The study is part of a descriptive, interpretive, and reflexive process, framed in a qualitative approach. For data collection, we used participant observation, observation log grids, field notes, photographic records, and interviews with the children. After analyzing the data, these tend to reveal, among other aspects, a remarkable improvement in motivation of children, perceiving that the game is an excellent teaching/learning strategy that allows the development of social and communication skills of children, predisposing the child for learning. As far as the type of game support is concerned, we found that although digital is more appealing to children born in the Digital Age, we verified that both the game in analog and digital support, when properly integrated into the educational action, are also promoters of meaningful and lasting learning.
\end{abstract}

Keywords: Initial teacher training; game; analog game; digital game; Teaching of the 1st Cycle of Basic Education. 


\section{Introduction}

In this article, we intend to deepen the knowledge about analog and digital games as a pedagogical resource, its relation with the teaching-learning process, and also to understand how the type of support affects the motivation of children. Through play activities, the child develops psychologically, culturally, socially, mentally, and physically; that is, play provides an integral development of the human being.

Given the importance of play activities for child development, how do the different game supports (analog/digital) motivate children through the learning process? In order to answer this question, we have outlined the following objectives: i) to understand if the type of support in which children play influences learning; ii) develop activities in contexts, using games (analog and digital); (iii) understand, to what extent, playing games encourages the development of multiple skills. In the course of this research, we find that, increasingly, children need diversified teaching methods that stimulate their taste in learning, keep them interested and enthusiastic, and make their learning more meaningful. Increasingly, we hear of the game as a powerful educational resource that, when used consistently, becomes a pleasant and successful promoter of the teaching-learning process of children, since according to Serrão (2009), "the game can constitute a resource to promote the articulation of content in the pedagogical practice of [teachers], in different strategies, in the development of children's learning" (p. 1).

According to Sousa and Baptista (2014), the research on the practices presented here focuses on "understanding problems, analyzing behaviors, attitudes or values" (p. 56). In this article, we present a brief theoretical framework through which we seek to base this research, the methodology that underlies the study, the discussion of results, final considerations, and bibliographical references.

\section{Theoretical Framework}

The game in Piaget's theory

Throughout his work, Piaget (1990) has always given great importance to play in children's development. Pessanha (2003) mentions that Piaget "presented a theory related to the child's cognitive development. He considered that children go through different stages of development and that, in play activity, the type of behavior is linked to the corresponding development phase" (p. 33).

For Piaget (1990), the development of intelligence in children is strongly linked to play activities, relating each type of game to a particular stage of the child's development. This author classifies games as related to the three stages of development: sensorimotor stage ( 0 to 2 years), preoperative stage (from 2 to 7 years), and concrete operations stage (from 7 to 11 years). 
In the initial form of the game, the child becomes aware of new abilities; in each acquired learning, the child returns to use these games that end up forming new schemes of action or conduct. The purpose of these games is the repetition of movements and gestures just for the pleasure that the child has in doing them. In exercise games, there are no symbols or rules.

Then the child moves on to symbolic games, in which he still finds the same pleasure as previous games, but he begins to use symbols (Tarman \& Tarman, 2011). There is, therefore, the presence of the make-believe where the child uses other objects to symbolize that he is eating, sleeping, or doing any other activity. This behavior represents some situation that the child experienced, allowing the assimilation of the outside world with the child's self (Baytak et al, 2011; Valiandes \& Tarman, 2011).

Symbolic games evolve to age 7. In the first years of this phase (from two to four years), the child uses his own body to represent what he wants; for example, imitating animals, in the case of the dog, the child kneels and imitates the sound of the dog. However, when approaching the stage of concrete operations, around the age of 7, intuitive thinking begins to emerge and games begin to have a closer representation of reality. Here the child seeks pleasure through the obtained results and the fulfillment of rules, whereas in symbolic play, pleasure is in the process. This is the phase of the rules game. In conclusion, for Piaget (1990), playing is crucial in the child's life, constituting a condition for the social, moral, intellectual, and cognitive development of the child.

\section{The game in Vygotsky's theory}

Like Piaget, Vygotsky considers game/ludic as a fundamental factor in the development of children, establishing a relationship between this and learning.

For this psychologist, it is only around age 3 that the game arises in the activities of children, since until that age the child still cannot understand symbols to represent the real through the imaginary. In this way, Vygotsky (2008) believes that it is in the imaginary world of the child that the game ascends, where the child is an active being that builds and creates through social interactions.

According to the psychologist, the child's game presents three main characteristics: imagination, imitation, and rules. When playing, the child imitates everything he sees and experiences in daily life, using his imagination. Thus, "the imaginary action created by the game favors the development of abstract thinking and the maturation of social rules" (Baranita, 2012, p. 41).

Vygotsky's most well-known theory concept is the Zone of Proximal Development (ZPD), which "defines those functions that have not yet matured but are in the process of maturation, 
Riberio, M. C. Analog and Digital Games as a Pedagogical Tool in the Teacher Training Context.

functions that will mature but are presently embryonic" (John-Steiner, Souberman, Cole, \& Scribner, 2007, p. 97). It is essential that the child has opportunities to play, know, experience, feel, discover, explore, create, and interact in order to develop skills. Vygotsky's theory emphasizes the teacher's responsibility for the development of the child. It is fundamental that in their pedagogical practices, teachers use games and ludic activities with the purpose of providing children with excellent experiences so that they can be developed and learn with greater ease.

For Vygotsky, when the teacher proposes game situations in the classroom, he offers moments of affection between the child and learning, making learning more meaningful and enjoyable.

\section{The game as a pedagogical resource}

The role of game in the development and education of children in playing is, as Pessanha (2003) states, "one of the most common forms of behavior during childhood and highly attractive and intriguing for researchers interested in human development, education, health and social intervention" (p. 5).

Nowadays, children have access to diverse means of communication so that the way the contents are approached in school becomes a little discouraging. The oral presentation of ideas is the technique most used by teachers, allowing them to promote information in a more synthetic and orderly way. This method, "the expository method also makes content management much more objective and linear. Saves time. It makes the alibi rarer from lack of time to fulfill programs. Managing the programs in this way is easy to accelerate in the teaching when it is necessary" (Ribeiro, 2012, p. 72).

However, we know that children of all ages have a taste for play. The period of childhood is deeply related to play and games. Thus, the game can be transformed into an educational support and as a way of motivating children to learn. The game, as a learning tool, is a resource with enormous interest for teachers, since its importance is directly linked to the development of the human being in a social, creative, affective, historical, and cultural perspective. According to Couto (2018), "the use of the game as a teaching and learning strategy helps to build a more motivating learning environment" (p. 17). We can point out that the game is a development opportunity. Thus, when playing, the child experiences, invents, discovers, learns, and confers skills. Therefore, we corroborate Teixeira and Apresentação's (2014) opinion that "the use of the game as pedagogical material aims to create a relaxed environment that enables meaningful learning through observation, creativity, logical thinking, problem situation, articulation with different knowledge and interrelation with classmates" (p. 305). However, it is important to note that not all games are included in the pedagogical material category; the element that separates an educational game from a more playful one is that games or pedagogical toys are developed with the explicit intention of provoking meaningful learning, 
Riberio, M. C. Analog and Digital Games as a Pedagogical Tool in the Teacher Training Context.

construction of new knowledge, and awakening the development of an operative skill (Antunes, 2011, p. 38).

Thus is the role of the teacher in the selection of the games highlighted.

Digital games in the teaching-learning process

The game plays a huge role in all children's lives. Therefore, in today's intimately technological world, the way of interacting with games is changing. With the technological expansion and the great ease in acquiring computer products, children have contact with other activities of this nature such as computer games or digital games. In this sense, Silva, Marques, Mata, and Rosa (2016) state that "technologies have a strong attraction to children and play an important role in their daily life, it is important that they be supported early on to make a critical reading of this influence, to understand their potentialities and risks and to know how to defend themselves against them" (p. 93).

Digital games, in an educational context, can become a powerful learning tool as the child is encouraged to participate, improving performance and stimulating the generation of individual, collective, and social experiences. According to Amante (2011), the computer stimulates an active learning, controlled by the student, in which we point out the role of the teacher, as mediating agent, in order to guide the game to the learning to be stipulated in its planning.

The game's role in the stimulation of multiple intelligences

After integrating a research team dedicated to studying human potential, psychologist Howard Gardner created the Theory of Multiple Intelligences. This theory holds that the human being has eight intelligences located in different parts of the brain, which can be stimulated in different ways. They are (i) linguistic intelligence, referring to an individual's ability to express himself either through oral language or gestures, as a way of analyzing and interpreting ideas and information, and producing works involving oral and written language. According to Antunes (2011), in order to develop this competence, the teacher can propose games that allow the child's vocabulary to expand, games that develop fundamental language skills such as analyzing, comparing, synthesizing, describing, and criticizing grammar and games for verbal memory; (ii) logical-mathematical intelligence, referring to conclusions based on the reason that games must "fix the symbolic conceptualization of numerical and geometric relations ... to awaken the operative and meaningful awareness of numbering systems" (Antunes, 2011, p. 71). Thus, memory games, bingos, board games, and imitation games are some examples of play activities that develop logical-mathematical intelligence; (iii) spatial intelligence, which is linked to visual and spatial perception, to the interpretation and creation of visual images and to the pictorial imagination, making possible a better understanding of graphic information such as maps. Games aimed at stimulation of this nature should work on the notions of location and direction, spatial-temporal orientation, and creativity, such as drawing and painting 
Riberio, M. C. Analog and Digital Games as a Pedagogical Tool in the Teacher Training Context.

activities, construction games, and blind goat, among others; (iv) musical intelligence, which involves understanding and expression through music, the ability to compose and reproduce musical patterns. Ludic activities play a very important role in the development of this competence, since a lot of the games are accompanied by rhythms, sounds, and music. Thus, providing games in which the child can hear different sounds and playing musical instruments are some playful activities that favor the development of this competence; (v) body-kinesthetic intelligence translates into the ability to control body movements, balance, coordination, and express oneself using the body; (vi) interpersonal intelligence refers to an individual's ability to relate to others, and in order to develop this competence, it is necessary to have human contact, teamwork, and communication; (vii) intrapersonal intelligence is linked to each person's ability to recognize their unconscious habits, modify their attitudes, and control addictions and emotions. It is important that in these situations, the teacher praises and values the performance and not only the victories; (viii) naturalistic intelligence, which, according to Lima and Lima (2003), involves the observation and understanding of the environment and natural elements such as fauna and flora. As a way of developing this ability, the teacher can carry out activities/games involving the imitation of animal sounds, dramatization of facts related to nature (pollution, animals facing extinction, etc.), and games with names of animals and plants, among others. Although this intelligence did not appear in his early works, Gardner decided to include it later. With this research, Gardner's main goal was to show the plurality of the human intellect and how these competencies can be developed.

\section{Methods}

The research described has analogical and digital games as a pedagogical tool in the context of teacher training. It focuses on children's learning and was developed from a qualitative perspective (Bogdan \& Biklen, 2013). Considering the context of carrying out this exploratory study, the Supervised Teaching Practice, this focused on a question that, limiting this research, made it feasible in time conditions in which it was performed. The question is: How do different game supports (analog/digital) motivate the children to the teaching-learning process? In order to answer this question, we outlined the following objectives: i) to understand if the type of support in which children play influences their motivation; ii) develop activities in contexts, using the game (analog and digital); (iii) understand, to what extent, playing games encourages the development of multiple skills.

The technique of data collection that we used most frequently during this investigation was participant observation, since the researcher "integrates the means to investigate, thus being able to have access to the perspectives of the people with whom they interact, while living the same problems and the same situations as them" (Sousa \& Baptista, 2014, p. 88).

Field notes, to which we also refer, are characterized as instruments of data collection providing a more detailed description of events, people, objects, and activities. These are, therefore, a kind of written account of all that the investigator observes at a given moment. Bogdan and 
Riberio, M. C. Analog and Digital Games as a Pedagogical Tool in the Teacher Training Context.

Biklen (2013) consider that "the field notes are fundamental for participant observation" ( $p$. 150).

As a complement, we used the semi-structured interview, which is based on a script called "with a set of topics to be addressed in the interview" (Sousa \& Baptista, 2014, p. 80). The interview carried out with children of the First Cycle of Basic Education came up with the objective of knowing the children's perceptions about the theme under study. To this end, we consider it was pertinent to interview the children about their playing habits, both in school and at their homes, and to know their opinions about the games they have explored along our way through their classroom.

From the analysis of these data emerged conclusions, presented in the discussion of the results.

\section{Results and Discussion}

According to the objectives indicated for this study, these would allow us to guide the answer to the main question; the use of this resource undoubtedly motivated the children, having demonstrated in class several competences. With regard to the research presented here, through which we wanted to know how the different game supports (analog/digital) motivate children in the teaching-learning process, we begin by saying that we believe we have succeeded in obtaining a response to it. During our practice, it was possible to observe the great enthusiasm of the children in the accomplishment of the tasks. When we used the game as a resource, we found enthusiastic involvement and sharing of know-how. With this research, we realize that the game (regardless of the support) is a great ally in the construction of learning.

With regard to the objectives outlined in the question, we consider that we have also managed to achieve them. Concerning the first objective, to see if the type of support in which children play influences their motivation, we concluded that the children were more enthusiastic when they discovered that they were going to play on the computer; however, by our observations, we conclude that, regarding the efficacy of the game in educational terms, both analog and digital support, when strategically and methodologically put into practice, are promoters of meaningful and lasting learning. Of course, the computer becomes a much more attractive object, as today's children are "born" with the technologies that are very present in their lives.

The second objective, to develop activities in the contexts using the game (analog and digital), was also achieved and is visible in the different registers that we carried out during our practices.

In respect to the third objective, to understand the extent to which playing games favors the development of multiple skills, we can say that through play, children develop affective bonds with each other, helping to build more socializing learning in addition to the great motivation, strengthening their sense of inter-help, consolidating certain values that help them to live with 
Riberio, M. C. Analog and Digital Games as a Pedagogical Tool in the Teacher Training Context.

others democratically. Therefore, the game allows children to put aside individualism, helping them to their future in society.

To conclude, we present the data that emerged from the content analysis, which focused on knowing some children's habits regarding the games they usually play at school and at home. They say they prefer to play checkers, puzzles, and Who is Who? There are also answers that refer to memory games, dominoes, chess, and games related to fights. These facts are evidenced in the following: "The game checkers is what I like the most" (C1); "(...) checkers and Who is Who?" (C4); "It's a game about the contents of the classes, which has problems. It's Mathematics and Study of the Environment and then we have to say the answer" (C16).

Through the analysis of the registration units, we can also verify that in all of the games available in the school's library, children usually explore games that challenge reasoning, such as chess, checkers, and puzzles, among others. However, it appears to be children who resort to games that explore the content addressed in educational practices. When questioned about whether the games in the library would be sufficient, 13 of the 17 children said yes, but the remaining four children mentioned their desire to have more variety of games through which to learn some content: "Yes [there should be more]. Those with questions of Study of the Environment, Mathematics, Portuguese, English. So instead of studying in books, we would play games."

Therefore, for us to get an idea of the contact with games in their homes, we asked: "Do you have a computer at home? If so, what do you usually do?" As far as the first question is concerned, only one child responded negatively, with the remainder having computers available in their homes. Regarding the second question, 13 children reported using the computer to view videos and play games; we can confirm this statement from the excerpts. One child said he used the computer to play games and also to search for tests and information about some school contents: "I also played some games and looked for some tests on the matter."

Then, in order to know their opinion, we asked them about the classes in which we used games to explore/review some of the content taught. In this way, 12 children reported that these classes were more stimulating, since their approach was not like normal, in which the contents are explored in a transmissive way, becoming a bit monotonous. It is possible to verify this last statement through the excerpt: "When you played games, we learned while we were playing" (C1); "They were cool, because we had fun and at the same time learned things" (C2). Also, in response to the previous question, a child considered the classes in which we used the game as: "It is a good way to entertain children, different than always talking about the same subject" (C8). Through the reports presented, it is noticeable that the games developed during our practice in this context were a remarkable strategy because they not only provided moments of pleasure for the children but also contributed to the development of their learning. 
Riberio, M. C. Analog and Digital Games as a Pedagogical Tool in the Teacher Training Context.

Finally, as a way of trying to know if game support (analog/digital) had any influence on the involvement of children, we asked them about their preference in the type of support and the reason. Six of the 17 children interviewed prefer board games, since: "we are the ones who move the pieces and the dice. And also, because we interact with colleagues more than in the computer" (C1). Four children reported having a preference for games in a digital format: "we learn things better and we do not need to throw the dice, just click" (C5). The remaining seven children considered both supports as facilitators in the teaching-learning process: "They are both good, I do not have one preferred because I think we learn both" (C10).

By the answers to the questions, it is possible to observe the perceptions of the children on the use of the game as an educational resource. For them, the pleasure of the game coupled with the possibility of learning becomes a factor of great motivation.

\section{Conclusion}

One of the purposes of this investigation was to demonstrate that the game appears in a child's life as a source of extremely pleasurable knowledge. Thus, the game, with its playful and educational function, provides entertainment and socialization among children and between children and adults. It is in the activities developed by teachers that children begin the discovery of the world, preparing for their roles in society.

The game, when applied well, can be much more than a recreational instrument. More than that, the role of games in education is of enormous relevance since through playing/ludic, the child acquires skills and, at the same time, develops in a social, cognitive, affective, and motor way. In this way, using games in a school context can promote a fascinating and enjoyable environment while promoting the learning and development of children.

During our observation/cooperation period in the First Cycle of Basic Education class, due not only to the organization of the space and to the fact that it was a level of education promoting formal learning, it was a little more difficult to develop activities using the game as a strategy of teaching-learning. In relation to the involvement of children in a situation of play, we found that there was a great curiosity and attention on the part of these; however, it is important to point out that although the game stimulates and motivates the children in their learning process, forced use without pedagogical intention can cause disinterest for the same, but educational games are intended to socialize and educate. During this investigation, we could verify that, from game to game, there was evolution of each child in the various domains of development and learning, which leads us to conclude that the game has a significant role in the education of children, both in the playful field and in the pedagogical aspect. 
Riberio, M. C. Analog and Digital Games as a Pedagogical Tool in the Teacher Training Context.

\section{References}

Amante, L. (2011). As Tecnologias digitais na escola e na educação infantil. Pinhais: Editora Melo.

Antunes, C. (2011). Jogos para a estimulação das múltiplas inteligências. Petrópolis: Editora Vozes.

Baranita, I. (2012). A Importância do jogo no desenvolvimento da criança. Lisboa: Escola Superior de Educação Almeida Garrett.

Baytak, A., Tarman, B., \& Ayas, C. (2011). Experiencing technology integration in education: Children's perceptions. International Electronic Journal of Elementary Education, 3(2), 139-151.

Bogdan, R., \& Biklen, S. (2013). Investigação qualitativa em educação. Porto: Porto Editora.

Couto, C. (2018). O jogo como estratégia de ensino e aprendizagem em geografia no 70 ano de escolaridade. Lisboa: Instituto de Geografia e Ordenamento do Território.

John-Steiner, V., Souberman, E., Cole, M., \& Scribner, S. (2007). Interação entre aprendizado e desenvolvimento. In L. S. Vygotsky (Ed.), A Formação social da mente (pp. 90-135). São Paulo: Martins Fontes.

Lima, J. M., \& Lima, M. R. C. (2003). A importância do jogo na perspetiva das inteligências múltiplas. Nuances: Estudos sobre educação, 9(10), 111-124. Retirado de http://revista.fct.unesp.br/index.php/Nuances/article/view/400/435.

Pessanha, A. M. A. (2003). Actividade lúdica associada à literacia. In C. Neto (Ed.), Jogo \& desenvolvimento da criança (pp. 151-169). Lisboa: Instituto de Inovação Educacional.

Piaget, J. (1990). A Formação do símbolo na criança. Rio de Janeiro: Zahar Editores S.A.

Ribeiro, G. M. (2012). O Ensino da história. Lisboa: Fundação Francisco Manuel dos Santos.

Serrão, E. M. F. L. (2009). O Educador de infância e o jogo no desenvolvimento da criança. Lisboa: Universidade de Lisboa.

Silva, I. L., Marques, L., Mata, L., \& Rosa, M. (2016). Orientações curriculares para a educação pré-escolar. Lisboa: Ministério da Educação/Direção-Geral da Educação (DGE).

Sousa, M. J., \& Baptista, C. S. (2014). Como fazer investigações, dissertações, teses e relatórios. Albergaria-a-Velha: Factor.

Tarman, B. \& Tarman, I. (2011). Teachers' Involvement in Children's Play and Social Interaction, Elementary Education Online (Ilköğretim Online), 10 (1). 180-194.

Teixeira, R., \& Apresentação, K. (2014). Jogos em sala de aula e seus benefícios para a aprendizagem da matemática. Revista Linhas, 15(28),302-323. Retirado de http://revistas.udesc.br/index.php/linhas/article/view/1984723815282014302/3103 
Valiandes, S. \& Tarman, B. (2011). Differentiated Teaching and Constructive Learning Approach by The Implementation of ICT in Mixed Ability Classrooms, Ahi Evran University Journal of Education Faculty, (KEFAD)12 (1), 169-184.

Vygotsky, L. S. (2008). Pensamento e linguagem. Lisboa: Relógio D’Água. 